\title{
Coping strategies of the leaders of the agro- industrial complex of the Rostov Region
}

\author{
Anna Karamysheva ${ }^{1}$, Anastasia Kolenova ${ }^{1}$, Anna Kukulyar $^{1}$, Natalya Bessonova ${ }^{2}$, and \\ Ditry Stroyev ${ }^{1}$ \\ ${ }^{1}$ Don State Technical University, 344003, Rostov-on-Don, Russian Federation \\ ${ }^{2}$ Center for Psychological Correction "Elephant", 344003, Rostov-on-Don, Russian Federation
}

\begin{abstract}
Today, the agro-industrial complex is the most important factor in the formation and development of the Russian economy. In the modern market economy of Russia, special attention is paid to the personality of the head of the agro-industrial complex. In connection with the development of the economy and technological progress, society is increasingly in need of an increase in the number of qualified and successful representatives of the management apparatus of this industry. On the basis of which we conducted an empirical study, where the object was 40 managers of various pilot production enterprises of the Rostov region. In the course of the empirical study, the following methods were used: "The scale of basic beliefs" (in the modification of M. A. Padun, A.V. Kotelnikova), Proactive coping inventory in the adaptation of E. Starchenkova, "Methods of coping behavior " by R. Lazarus and S. Folkman, the Life Style Index (LSI). These recommendations can be taken into account by managers and employees of personnel services of enterprises of the agro-industrial complex when forming systems of motivation and development of the highest needs of employees holding managerial positions in modern market conditions.
\end{abstract}

\section{Introduction}

Coping strategies, as strategies for coping with a stressful situation, were studied by N.E. Vodopyanova, T.V. Kryukova, E.I. Rasskazova, T.O. Gordeeva. Also, scientific studies were carried out on the influence on the choice and implementation of coping strategies of age, gender, cultural and professional personality characteristics (B.F. Lomov, T.E. Argentova, V.M. Voinenko, N.A. Sirota, E.V. Topolova, V.M. Yaltonsky, J. Birkimer, L. Sulsky, V. Cleaver). At present, coping behavior is considered in a large age range - from preschool age to old age (G.A. Vilenskaya, R.M. Granovskaya, T.V. Gushchina, M.V. Saporovskaya, etc.), gender analysis is also widely presented. coping strategies (N.O.Belorukova, O.B. Podobina and others), the study of family coping was carried out by such scientists as: M. Bowman, S. Norman, D.F. Endler, T.A. Kryukova, E.V. Kuftyak and others [1-4].

\footnotetext{
*Corresponding author: kolenova.nastya@yandex.ru
} 
However, at the moment, coping strategies remain poorly studied among representatives of the management apparatus of the agro-industrial complex. The choice of coping strategies is influenced by both socio-demographic factors and the personal characteristics of coping subjects. We assumed that self-actualization, as a personality trait, aimed at a person's continuous striving for development, individuality, and effective implementation of the system of his potentials, can have a significant impact on the choice of coping strategies among representatives of the management apparatus of the agro-industrial complex. The problem of self-actualization of the individual in psychology was dealt with A. Maslow, K. Goldstein, D. Kelly, G. Murphy, R. May, G. Murray, G. Allport, K. Rogers and others were involved in the problem of personality self-actualization in psychology. In Russian psychology, self-actualization is studied as a mechanism of self-development that makes his need, goal and life strategy (T.I. Artemieva, K.A. Abulkhanova-Slavskaya, E.I. Golovakha). Self-actualization as an indicator of personal maturity is considered in the works of V.M. Rusalova, I.N. Sviridenko, E.A. Sergienko, E.V. Stolyarskaya [10].

\section{Discussion}

Coping strategies are a broad concept with a long and complex history [2, 3, 4]. L. Murphy in 1962 first used the term "coping" in the psychological literature, when studying ways to overcome developmental crises in children. Four years later, in 1966, R. Lazarus in his book "Psychological Stress and Coping Process" ("Psychological stress and the process of coping with it") turned to the concept of coping to describe the deliberate strategies of action to overcome stress and other events that generate anxiety. They became interested in the study of coping back in the 1940-1950s, and at present there are a large number of definitions of this concept in psychology. Coping in Russian psychology is studied within the framework of the study of psychological stress as a mechanism for overcoming it $[4,5]$.

Coping behavior was studied in the 90 s of the XX century and is associated with the work of scientists such as L.I. Antsyferova, K.K. Platonov, B.M. Teplov et al. [8]. The essence of coping behavior is that a person overcome negative life experiences or reduce their impact on the body. In this publication, we will adhere to the position that coping behavior is "purposeful social behavior that allows the subject to cope with a difficult life situation (or stressor) in ways that are adequate to personality characteristics and the situation, through deliberate action strategies" [9]. Coping behavior is aimed at increasing the adaptation of the individual to the environment and is formed through a set of coping strategies - specific coping actions. In addition to coping strategies, I also highlight coping resources of the individual, which are divided in turn into [7]: Social resources, Physical resources, Psychological resources (self-esteem, intellect, humor), Material resources (money) [7, 8, 9].

In overcoming difficult situations, an important role is played by the internal resources of the individual. Such as the locus of control, which determines the degree of acceptance of responsibility in confronting life's problems; reflexive ability helps a person concentrate on a problem to choose the best solution; persistence, social courage, high achievement motivation and normative behavior, which help in overcoming fears and doubts $[11,12]$.

When studying psychological literature, it becomes clear that coping is now a popular phenomenon that arouses keen interest among both foreign and Russian scientists, and the agro-industrial sector is no exception. Coping strategies are extremely diverse. With the help of various studies, more than 400 strategies for overcoming life difficulties have been identified today [7], and many attempts have been made to classify them, but one generally accepted classification does not yet exist. 
However, there are three main approaches to understanding coping. The first approach is situational, within the framework of which it considers the coping process as a specific ego mechanism that a person resorts to in order to get rid of internal tension.

Dispositional - this is the second approach - coping here is a set of relatively stable, personal characteristics that act as a prerequisite for an individual's response to a stress factor.

The third is an integrative approach - here coping is already considered as a dynamic process that depends on the phase and situation of interaction with stress and on the cognitive assessment of the stressor by the person himself [7].

The specifics of the labor activity of the head of the agro-industrial complex requires him to have certain personal qualities, such as purposefulness, organization, entrepreneurial and professional activity, social and professional mobility, sociability and the ability to cooperate, creative approach, aesthetic sensitivity, special, socio-legal and auto competence, professional self-awareness. One of the conditions for the successful development of professional personal qualities of a leader is the development of higher needs and the implementation of the necessary coping strategies $[11,12,13,14,15]$.

\section{Research methods and techniques}

To study coping behavior strategies among the leaders of the agro-industrial complex of the Rostov Region, we used the following methods: Basic Belief Scale (SBB1) (Ronnie Yanoff-Bulman modified by M. A. Padun and A. V. Kotelnikova), Questionnaire of Proactive Coping Behavior (coping) (eng. Proactive Coping Inventory, abbreviated PCI) in the adaptation of E. Starchenkova, "Methods of coping behavior of R. Lazarus and S. Folkman, Life Style Index (LSI). The object of the research was 40 heads of various experimental production enterprises of the Rostov region. The entire group of respondents was divided into 3 subgroups based on the SBU-1 methodology. Thus, group 1 is represented by leaders with low indicators of a sense of security - 13 people (32\%), group 2 - with average indicators of a sense of security - 12 people (30\%) and group 3 - with high indicators of a sense of security - 15 people (38\%). Research hypothesis - there may be differences in coping strategies among the leaders of the agro-industrial complex of the Rostov Region.

\section{Research results}

According to the data on the methodology "questionnaire of proactive coping behavior", the leaders of group 1 are dominated by the values on the scales: "preventive overcoming" (23), "proactive overcoming" (29) and "reflexive overcoming" (22).

The leaders from the second group are dominated by the values on the scales: "reflexive overcoming" (30), "preventive overcoming" (25) and "proactive overcoming" (34). Among the leaders of the third group, values prevail on the scales: "proactive overcoming" (43), "reflexive overcoming" (29) and "seeking emotional support" (12).

Next, we carried out the methodology "coping strategy questionnaire R. Lazarus ". We have identified the criteria for evaluating the results obtained: 1. The subjects have a low level of tension, then the coping variant is adaptive; 2 . The subjects have an average level that is the adaptive potential of the personality in the borderline state; 3 . The subjects have a high level - high intensity of coping, pronounced maladjustment (Fig.1). 


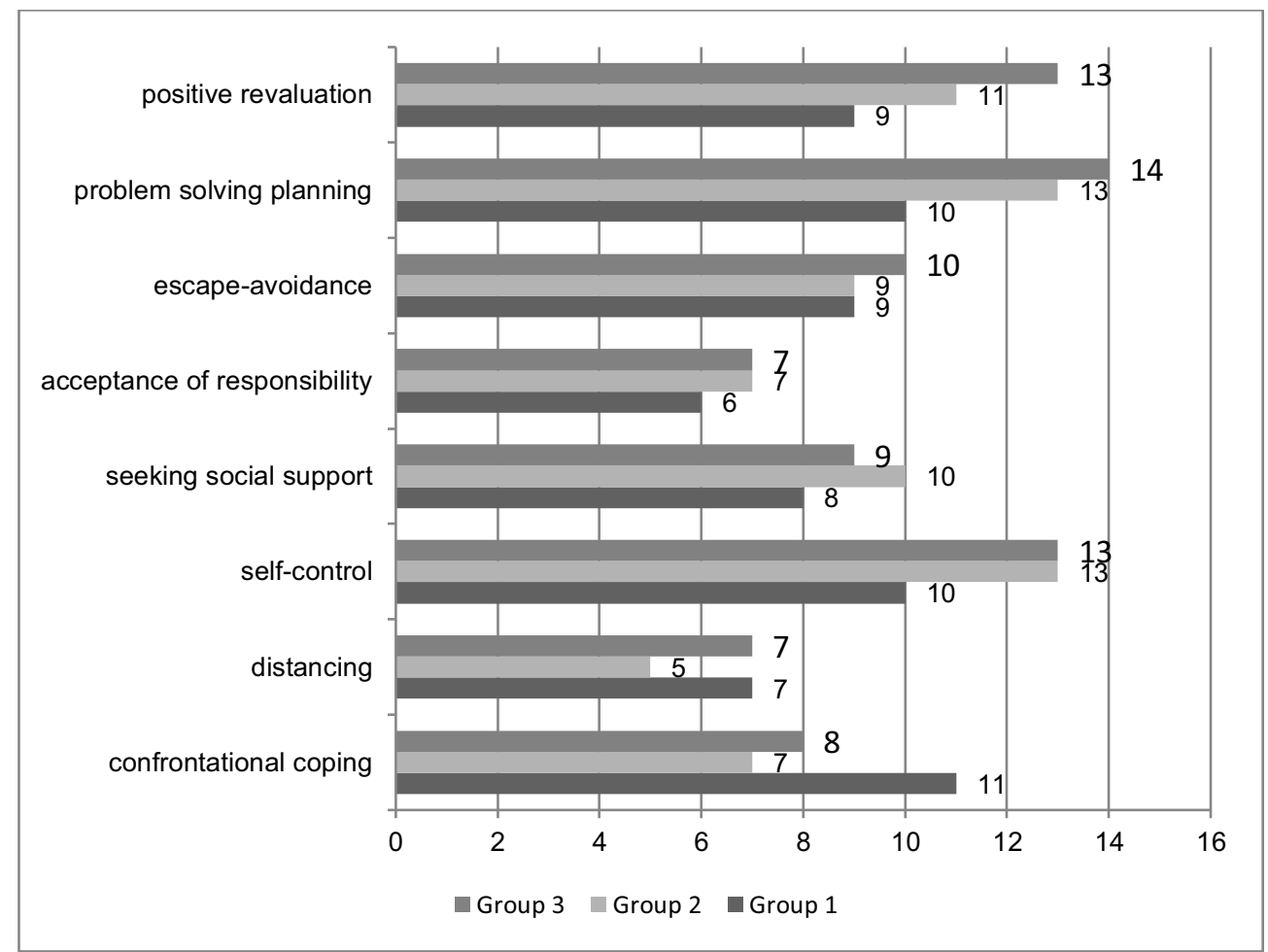

Fig.1. Average indices of raw points according to the methodology "R. Lazarus' coping strategy questionnaire" among three groups of managers.

Summarizing the data obtained by the methodology "R. Plutchik's life style index", we can conclude that managers with a low level of trust in the world have expressed such mechanisms of psychological defense as projection and repression. This explains their low level of trust in this world. They skillfully transfer all their fears, failures, disadvantages and problems to other people and attribute their own shortcomings to them. With the help of the repression mechanism, these subjects try to protect their "I", which is not able to cope with temptations on its own. Speaking about the leaders of the second and third groups, the mechanisms of psychological defense prevail among them: "rationalization" and "regression". For these groups of managers, reflection is a familiar way to deal with stress. The mechanism of rationalization is a way by which leaders find completely logical explanations for what is happening, and they also reduce the significance of what is happening for themselves and for others. Another protection mechanism for these managers is "regression". With the help of this mechanism, managers in a conflict or frustrating situation go to earlier stages of libido development.

\section{Conclusion}

Next, we present the results of the statistical analysis according to the Kruskal-Wallis Htest for the 3 groups of leaders we designated earlier with respect to each technique. Where there is 1 group of leaders of the agro-industrial complex with low indicators of a sense of security, 2 a group of leaders with average indicators of a sense of security, and 3 a group of leaders with high indicators of a sense of security. 
Table 1. The results of the analysis of variance between the averaged data for the "SBU" R. Yanoff-Bulman and the distribution of respondents into groups.

\begin{tabular}{|c|c|c|c|c|c|}
\hline & \multirow{2}{*}{$\begin{array}{l}\text { The benevolence of } \\
\text { the world }\end{array}$} & \multirow{2}{*}{ Justice } & \multirow{2}{*}{$\begin{array}{c}\text { Image } \\
\text { "I" }\end{array}$} & \multicolumn{2}{|c|}{$\begin{array}{c}\text { Validity of differences } \\
\text { (Kruskal-Wallis test) }\end{array}$} \\
\cline { 5 - 6 } & & & & $\mathrm{H}$ & $\mathrm{P}$ \\
\hline 1 group & 4.643 & 4.786 & 4.020 & 11.223 & 0.001 \\
\hline 2 group & 6.643 & 6.088 & 6.580 & 11.096 & 0.001 \\
\hline 3 group & 8.340 & 7.824 & 9.745 & 10.537 & 0.005 \\
\hline
\end{tabular}

The results obtained allow us to conclude that the distribution into groups based on the components we have identified is legitimate. Based on this, the statistical analysis will be carried out in relation to the 3 groups of respondents identified by us.

According to the "Proactive Coping Behavior Questionnaire", we obtained the following significant results, which are presented in Table 2 below.

Table 2. Results of one-way analysis of variance between the averaged data on the questionnaire of proactive coping behavior and basic beliefs of the respondents.

\begin{tabular}{|l|c|c|c|c|c|}
\hline & \multirow{2}{*}{$\begin{array}{c}\text { low scores for a } \\
\text { sense of } \\
\text { security } \\
\text { (1 group) }\end{array}$} & $\begin{array}{c}\text { average sense } \\
\text { of security } \\
\text { (2 group) }\end{array}$ & $\begin{array}{c}\text { high scores for } \\
\text { a sense of } \\
\text { security } \\
\text { (3 group) }\end{array}$ & \multicolumn{2}{|c|}{$\begin{array}{c}\text { Validity of differences } \\
\text { (Kruskal-Wallis test) }\end{array}$} \\
\cline { 5 - 6 } & & 4.786 & 4.020 & 11.223 & $\mathrm{H}$ \\
\hline $\begin{array}{l}\text { Proactive } \\
\text { overcoming }\end{array}$ & 4.643 & 6.088 & 6.580 & 11.096 & 0.001 \\
\hline $\begin{array}{l}\text { Preventive } \\
\text { overcoming }\end{array}$ & 6.643 & 7.824 & 9.745 & 10.537 & 0.005 \\
\hline $\begin{array}{l}\text { Reflexive } \\
\text { overcoming }\end{array}$ & 8.340 & & &
\end{tabular}

The obtained statistics allow us to assert that in group 1 with low indicators of a sense of security, proactive, preventive and reflexive overcoming will be the highest. Thus, it will be inherent in managers with low indicators of a sense of security to constantly assess possible stressors, analyze problems and available resources, as well as generate a proposed action plan, predict the likely outcome of an activity and choose ways to carry it out.

For a group with average scores of a sense of security, this proactive coping behavior will be typical, but to a lesser extent. For leaders from group 3 (high level of security), this type of coping behavior will be the least characteristic.

According to the "R. Lazarus coping strategy questionnaire", we obtained the following results, which are presented below in Table 3.

Table 3. Results of one-way analysis of variance between the averaged data on the coping strategies questionnaire and the basic beliefs of the respondents.

\begin{tabular}{|l|c|c|c|c|c|}
\hline \multicolumn{1}{|c|}{ Scales } & \multirow{2}{*}{$\begin{array}{c}\text { low scores } \\
\text { for a sense of } \\
\text { security } \\
\text { (1 group) }\end{array}$} & $\begin{array}{c}\text { average } \\
\text { feeling of } \\
\text { security } \\
\text { (2 group) }\end{array}$ & \multirow{2}{*}{$\begin{array}{c}\text { high scores } \\
\text { for a sense of } \\
\text { security } \\
\text { (3 group) }\end{array}$} & \multicolumn{2}{|c|}{$\begin{array}{c}\text { Validity of } \\
\text { differences } \\
\text { (Kruskal-Wallis test) }\end{array}$} \\
\cline { 5 - 7 } & 9.214 & 11.885 & 13.850 & 14.794 & 0.001 \\
\hline Positive revaluation & 10.357 & 13.231 & 14.438 & 17.883 & 0.001 \\
\hline $\begin{array}{l}\text { Problem solving } \\
\text { planning }\end{array}$ & 10.214 & 13.885 & 13.850 & 14.794 & 0.001 \\
\hline Self-control & 9.033 & 9.869 & 10.889 & 11.223 & 0.003 \\
\hline Escape-avoidance & & &
\end{tabular}


Analysis of the statistical data obtained allows us to conclude that in group 3 it is typical for managers with a high sense of security to exercise self-control to the maximum extent, plan ways to solve professional problems, and positively re-evaluate the experience gained. However, these same leaders try, if possible, to "bypass" problems in all possible ways.

For group 2 of managers, this behavior is also typical, but to a lesser extent. For respondents from group 1 it is also inherent, but to a lesser extent.

According to the methodology "Life style index" by R. Plutchik, we obtained the following results, presented below in Table 4.

Table 4. Results of one-way analysis of variance between the averaged data on the life style index questionnaire and the basic beliefs of the respondents.

\begin{tabular}{|l|c|c|c|c|c|}
\hline \multicolumn{1}{|c|}{ Scales } & $\begin{array}{c}\text { low scores for } \\
\text { a sense of } \\
\text { security } \\
\text { (1 group) }\end{array}$ & $\begin{array}{c}\text { average feeling } \\
\text { of security } \\
\text { (2 group) }\end{array}$ & $\begin{array}{c}\text { high scores for } \\
\text { a sense of } \\
\text { security } \\
\text { (3 group) }\end{array}$ & \multicolumn{2}{|c|}{$\begin{array}{c}\text { Validity of } \\
\text { differences } \\
\text { (Kruskal-Wallis } \\
\text { test) }\end{array}$} \\
\cline { 5 - 7 } & 8.533 & 9.774 & 9.500 & 10.537 & 0.005 \\
\hline Regression & 6.643 & 7.340 & 7.824 & 11.727 & 0.001 \\
\hline Rationalization & 9.786 & 5.580 & 6.088 & 14.403 & 0.005 \\
\hline
\end{tabular}

The analysis of the obtained statistical data allows us to conclude that it is typical for all 3 groups to resort to "Regression" and "Rationalization", which is reflected in behavioral reactions, managers seek to avoid anxiety by moving to earlier stages of libido development. With this form of a defensive reaction, a person exposed to frustrating factors replaces the solution of subjectively more complex problems with relatively simpler and more accessible in the current situations. Also, they are all characterized by an overly "mental" way of overcoming a conflict or frustrating situation without worries. In other words, subjects suppress experiences caused by an unpleasant or subjectively unacceptable situation with the help of logical attitudes and manipulations, even when there is convincing evidence in favor of the opposite.

Note that approximately the same values in the selection of all defense mechanisms were obtained in groups 3 and 2, i.e. with medium to high scores of sense of security.

The statistical data we obtained regarding each technique allowed us to say that the hypothesis that there may be differences in coping strategies among the leaders of the agroindustrial complex has been fully confirmed.

\section{References}

1. N.E. Vodopyanova, A.N. Kapustina, Bulletin of the Leningrad State University named after A. S. Pushkin, 5(1). (2015)

2. N.E. Vodopyanova, Provision of resources for combating professional burnout of the subjects of the work. St. Petersburg (2014)

3. E.A.Rasskazova, T.O. Gordeeva, E.N. Osin, Journal of the Higher School of Economics, 10(1), 82-118 (2013)

4. E.A.Rasskazova, T.O. Gordeeva, Personal potential: Structure and diagnostics. Ed. by D. A. Leontiev. Moscow: Smysl, 267-299 (2011)

5. E. V. Bityutskaya, Questions of psychology, 5, 138-150 (2014)

6. K. J. Aycock, Dissertation, Georgia State University, (2011) 
7. M.Hachaturova, The International Journal of Interdisciplinary Social and Community Studies, 7, 61-73 (2013)

8. M.V. Kozlova, Problems of modern Economy, 1, 14-19 (2015)

9. G.S. Korytova, Bulletin of the Tomsk State Pedagogical University, 4(132), 117-123 (2013)

10. M.N. Trushchenko, Psychological sciences: theory and practice: materials of the international scientific conference. Moscow: Buki-Vedi, 13-16 (2012)

11. V. I. Gerchikov, Textbook. Moscow: INFRA-M (2018)

12. I. Abakumova, A. Kukulyar, A. Kolenova, Rostovon-Don (2020) URL: Features of labor motivation of agro-industrial complex managers (e3s-conferences.org) doi.org/10.1051/e3sconf/202017515009

13. I.V. Krasnopevtseva, Monograph. - Samara scientific centre of RAS (2016)

14. I.N. Makhmudova, Abstract of the PhD thesis. Samara, (2013)

15. R.Janoff-Bulman, N.C. Carnes, Personality and Social Psychology Review, 17(3), 219-236 (2013) 